\title{
Determination of Factors Effective on the Organization of Dairy Cattle Farms: A Case Study of Van Province of Tuşba District ${ }^{\#}$
}

\author{
İbrahim Yıldırım, Mustafa Terin*, Kenan Çiftçi, Melike Ceylan, Bekir İlban \\ Department of Agricultural Economics, Faculty of Agriculture, Van Yuzuncu Yil University, 65080 Van, Turkey
}

\section{A R T I C L E I N F O \\ ${ }^{\#}$ This paper was presented at International Agricultural Science Congress held on 09- 12 May 2018 in Van, Turkey \\ Research Articles}

Received 29 August 2018

Accepted 22 October 2018

Keywords:

Dairy cattle farms

Agricultural organization

Ordered Probit model

Van Province

Turkey

\begin{abstract}
A B S T R A C T
The study aims at estimating the effect of producers' socio-economic characteristics and the farm structure on the probability of becoming a member of an agricultural organization. For this aim Ordered Probit Model was applied. The data of 2010 production period was collected from 66 dairy cattle farms through questionnaires based on stratified random sampling method. While $74.2 \%$ of producers were not a member to any organization, the remaining 18.2 and $7.6 \%$ were members of one and more than one organizations, respectively. The result of study showed that the variables of experience, education level, milk yields, milking machine existence, and record keeping rate increased the probability of becoming a member to any agricultural organization. Government financial, technical and educational supports towards increasing the number of cattle farms, with high educated and experienced labor and high productivity levels, which are associated in an agricultural organization, could promote the willingness of producers in the region in participating of agricultural organizations as a member.
\end{abstract}

\section{Süt Sığırcılığg İşletmelerinde Örgütlenmeye Etki Eden Faktörlerin Belirlenmesi: Van İli Tuşba İlçesi Örneği}

M A K A L E B İ L G İ S İ Ö Z

\section{Araştırma Makalesi}

Geliş 28 Ağustos 2018

Kabul 22 Ekim 2018

Anahtar Kelimeler:

Süt sığırcilığ1

Tarımsal örgütlenme

Siralı probit

Van

Türkiye

${ }^{*}$ Sorumlu Yazar:

E-mail: mustafaterin@yyu.edu.tr
Araştırmada, Van İli Tuşba ilçesinde süt sığırcılığı yapan tarım işletmelerinin tarımsal örgütlere (kooperatif, birlik vb. örgütler) üye olmalarını etkileyen sosyo-ekonomik ve işletmecilik özelliklerinin belirlenmesi amaçlanmıştır. Çalışmanın ana materyalini tabakalı örnekleme yöntemiyle belirlenen 66 adet süt sığırı işletmesinden elde edilen veriler oluşturmaktadır. Örgütlenmeye etki eden sosyo-ekonomik ve işletmecilik özellikleri sıralı Probit model kullanılarak analiz edilmiştir. Araştırma sonuçlarına göre, üreticilerin $\% 74,2$ 'sinin hiçbir tarımsal örgüte üye olmadı̆̆ı, \%18,2'sinin bir ve \%7,6'sının iki ve daha fazla tarımsal örgüte üye olduğu belirlenmiştir. Bunun yanı sıra araştırmada deneyim süresi, eğitim seviyesi, verim, süt sağma makinasına sahip olma ve işletmede kayıt tutma oranı arttıkça tarımsal örgütlere üye olma olasılığının arttığı belirlenmiştir. Bu sonuçlara göre özellikle deneyimli, eğitim seviyesi yüksek ve verimli süt sığırcılığı yapan işletmelerin sayılarının arttırılması ve modern işletmecilik ilkelerine göre faaliyet gösteren işletmelerin desteklenmesi bölgedeki diğer üreticilerin tarımsal örgütlere üye olmalarına pozitif yönde katkı sağlayabilecektir. 


\section{Introduction}

Some of the definitions of organizations are as follows: Co-existence, acting together, cooperating and institutionalization (Rehber, 2009), rational structures designed to fulfil specific objectives (Selznick, 1948), operational systems that are specially oriented, preconceived and coordinated (Daft, 2010), individuals with similar problems coming together to solve their problems (Talim et al., 1981, Inan et al., 2005; Eraktan, 2001).

Agricultural organizations in Turkey could be classified into groups, namely, economic-oriented and occupational-oriented ones (Yercan, 2007; Everst, 2015). Occupational organizations include Agricultural Chambers, Producers' Societies, Conservation Councils for Farmers' Services, Syndicates and agricultural foundations; while economical organizations make up agricultural cooperatives, producer associations and growers' associations aimed at improvement. (Koçtürk and Özbilgin, 2004, Yercan, 2007; Everest, 2015). The number of producers, who are the members to 11.572 agricultural cooperatives, 897 producers associations and 276 growers associations are 3.4 million, 354 thousands and 571 thousands, respectively (RTMFAL, 2018a).

The major aim of the organizations among the producers is increasing the agricultural productivity, thus, improving their income level (Inan et al., 2000). Given the small-scale and family-oriented structures of agricultural farms in the research area, agricultural organizations play a great role in competing against monopsonistics and oligopolistic markets and being sustainable in the process of production and marketing. Decreasing the production costs through these organizations would facilitate the farms to market integration (Chagwiza et al., 2016). Dairy cattle sector is known to be under strict competition nowadays, which requires to act together through the organizations.

A balanced nutrition is associated with sufficient milk production to meet the demand of ever-growing young population in Turkey (Y1ldırım et al., 2008). Dairy cattle farms contribute a lot in this regards, while exploit the labour, which is abundant on the surveyed farms, encourage production of feed plants and alleviating the migration to urban areas (Y1ldırım and Sahin, 2006). Dairy cattle farms, also, play a great role in saving currency reserves for more strategical import goods where the country has a low opportunity advantage.

The number of livestock amounted to 60 million in Turkey, including 16 million cattle, 34 million sheep and 11 million goats. Around 18.8 million tons of milk are produced annually from about 6.0 million milked cows. The milk yield per cow per year is 3.1 tons (RTMFAL, 2018b).

The study aims at determining the socio-economic and business characteristics, which affect the dairy cattle farms being members to agricultural organizations in Tuşba district of Van Province, Turkey.

\section{Material and Method}

The data of 2010 production period were collected from 66 culture-breed dairy cattle farms through questionnaires in Alaköy, Atmaca, Göllü, Kasımoğlu,
Mollakasim and Otluca villages, where dairy cattle activities are performed intensively. Sampling size were determined as 66 using the following stratified random sampling method with $10 \%$ error margin and $90 \%$ confidence limits (Yamane, 1967).

$$
\mathrm{n}=\frac{\mathrm{N} \cdot \sum \mathrm{N}_{\mathrm{h}} \cdot \mathrm{S}_{\mathrm{h}}^{2}}{\mathrm{~N}^{2} \cdot \mathrm{D}^{2}+\sum \mathrm{N}_{\mathrm{h}} \cdot \mathrm{S}_{\mathrm{h}}^{2}}
$$

The dependent variable is the number of agricultural organizations, in which the producers have memberships. The producers were classified into three categories, namely, those who have no membership to any agricultural organizations, those who are member of only one agricultural organization and those who have memberships to two or more agricultural organizations.

In this case, the dependent variable will have sequential and variable values as $(0,1,2, \ldots \mathrm{j})$. It is appropriate to use sequential probit and sequential logit models when there exist more than two dependent variables and there is a natural ordering between these variables (Abdel-Aty, 2001). The sequential probit model is based on the normal probability distribution, while the sequential logit model is derived from the standardized logistic probability distribution (McKelvey and Zavoina, 1975; Akın et al., 2000; Emeç, 2002). The feature that separates the sequential probit model from the sequential logit model is the normal distribution of errors. This study employs the sequential probit model estimation.

In the sequential probit model of observable, intermittent and ordered categories (y), it is assumed to be a continuous, but unobservable latent dependent variable. The unobserved, latent dependent variable $\left(\mathrm{y}^{*}\right)$ is explained by vector of explanatory variables and error term. The error term is assumed to have normal distribution (Greene, 2012).

$$
\mathrm{y}^{*}=\beta \mathrm{x}+\varepsilon \quad \varepsilon \sim \mathrm{N}[0,1]
$$

Where $\mathrm{y}^{*}$; unobserved dependent variable, $\mathrm{x}$; vector of explanatory variables, $\beta$; the parameter vector to be estimated and $\varepsilon$; error term (with normal distribution). The relationship between dependent variable (y) and nonobservable dependent variable $\left(\mathrm{y}^{*}\right)$ is treated as a function of threshold values $(\mu \mathrm{j})$ estimated separately using regression coefficients $(\beta)$.

The number of agricultural organizations in which producers are members were classified in three different categories ( $\mathrm{Y}=0,1,2)$. Thus, the relationship between the model dependent variable (y) and the non-observable dependent variable (y*) was as follows (Greene, 2012).

$$
\begin{array}{ll}
\text { if } \mathrm{y}^{*} \leq 0, & \mathrm{Y}=0 \\
\text { if } 0<\mathrm{y}^{*} \leq \mu_{1}, & \mathrm{Y}=1 \\
\text { if } \mu_{1} \leq \mathrm{y}^{*} & \mathrm{Y}=2
\end{array}
$$

The $\mu$ values in the equation are the threshold values that are estimated in the model and form the upper and lower bounds of the values, which y can take. The possibility of selecting one of the 3 alternatives (observed $\mathrm{y}$ values) in the sequential probit model is as follows (Greene, 2012). 
$\operatorname{Prob}(y=0 \mid \mathbf{x})=1-\Phi\left(\mathbf{x}^{\prime} \beta\right)$

$\operatorname{Prob}(y=1 \mid \mathbf{x})=\Phi\left(\mu-\mathbf{x}^{\prime} \beta\right)-\Phi\left(-\mathbf{x}^{\prime} \beta\right)$,

$\operatorname{Prob}(y=2 \mid \mathbf{x})=1-\Phi\left(\mu-\mathbf{x}^{\prime} \beta\right)$.

For all these probabilities to be positive, $\mu$ values must be $0<\mu 1<\mu 2<\ldots<\mu \mathrm{J}-1$. $\Phi$ indicates the cumulative normal distribution function. Direct interpretation of the coefficients of the variables of the ordered probit model estimated using the maximum likelihood method is not appropriate (Akbay et al., 2007). Since the effects of dependent variables on the probabilities depends on the values of dependent variables, they are not the same as parameter $(\beta)$ estimates. This requires estimating the marginal effects of the explanatory variables so that the effect on the probabilities can be determined. The marginal effects of the variables are calculated as follows for each probability (Greene, 2012).

$$
\begin{aligned}
& \partial \mathrm{P}(\mathrm{y}=0 \mid \mathrm{x}) \partial \mathrm{x}=-\varnothing\left(\mathrm{x}^{\prime} \beta\right) \beta, \\
& \partial \mathrm{P}(\mathrm{y}=1 \mid \mathrm{x}) \partial \mathrm{x}=\left[\varnothing\left(-\mathrm{x}^{\prime} \beta\right)-\varnothing\left(\mu-\mathrm{x}^{\prime} \beta\right)\right] \beta \\
& \partial \mathrm{P}(\mathrm{y}=2 \mid \mathrm{x}) \partial \mathrm{x}=\varnothing\left(\mu-\mathrm{x}^{\prime} \beta\right) \beta .
\end{aligned}
$$

\section{Results and Discussion}

The socio-economic qualities and behaviors of producers have an important role in their relationships with organizations (Chacko, 1985; Birchall and Simmons, 2004; Bhuyan, 2007). Some data related to sociodemographic and business characteristics of producers is summarized at Table 1 . Nearly $3 / 4$ of producers $(74.2 \%)$ are not members of any cooperative and union, while 18.2 and $7.6 \%$ of producers are members to one and two or more agricultural organizations, respectively.

In South Eastern Anatolia Project (GAP) area more than half of producers $(58.0 \%)$ had a memberships to one producers' organization while the memberships to two, three and four organization were 35.1, 5.2 and $1.7 \%$, respectively (Karlı and Çelik, 2003). Inan et al. (1999) reported that more than third of producers $(85.6 \%)$ had memberships to two or more producers organizations and $14.4 \%$ were members to only one organization in Thrace region of Turkey. In Van Province, Turkey, $16.9 \%$ of producers were not members to any agricultural organization, while more than half of them $(56.8 \%)$ had a memberships to only one organization followed by those who were members to two and three organizations with

\begin{tabular}{|c|c|}
\hline Variables & Values \\
\hline \multicolumn{2}{|l|}{ Dependent Variable } \\
\hline \multicolumn{2}{|l|}{ Number of Agricultural Organizations } \\
\hline no membership to any agricultural organizations & $\% 74.2$ \\
\hline one membership of agricultural organizations & $\% 18.2$ \\
\hline two and more membership of agricultural organizations & $\% 7.6$ \\
\hline \multicolumn{2}{|l|}{ Independent variables } \\
\hline \multicolumn{2}{|l|}{ Continuous Independent variables } \\
\hline Experience (years) & $25.92(10.88)$ \\
\hline Education (years) & $5.41(3.07)$ \\
\hline Milk yield (kg/cow/day) & $8.89(3.38)$ \\
\hline \multicolumn{2}{|l|}{ Binary Independent variables } \\
\hline (Having milking machine, 1 ; others 0 ) & $\% 16.7$ \\
\hline (Doing artificial insemination, 1 ; others 0 ) & $\% 31.8$ \\
\hline (Record keeping, 1 ; others 0$)$ & $\% 31.8$ \\
\hline
\end{tabular}
19.5 and 6.8\%, respectively (Terin and Çelik Ateş, 2016).

Table 1 Descriptive statistics of the variables

\begin{tabular}{|c|c|c|c|c|}
\hline Variables & Coefficient & St. Error & Z-statistics & P-value \\
\hline Constant & $-4.083^{* * * *}$ & 0.993 & -4.110 & 0.000 \\
\hline Experience & $0.044^{* *}$ & 0.021 & 2.110 & 0.035 \\
\hline Education & $0.168^{* *}$ & 0.080 & 2.100 & 0.039 \\
\hline Milk Yield & $0.101^{*}$ & 0.054 & 1.883 & 0.059 \\
\hline Milking machine & $0.886^{*}$ & 0.489 & 1.812 & 0.070 \\
\hline Artificial insemination & $-0.908^{*}$ & 0.505 & -1.799 & 0.072 \\
\hline Record keeping & $1.114^{* * *}$ & 0.409 & 2.719 & 0.007 \\
\hline $\begin{array}{l}\text { Threshold parameters } \\
\text { Mu (1) }\end{array}$ & 1.157 & 0.304 & 3.800 & $0.0001^{* * *}$ \\
\hline
\end{tabular}

Standard deviation values are given in parentheses.

Table 2 Ordered probit model estimation results 
Table 3 Marginal effects of factors

\begin{tabular}{|c|c|c|c|}
\hline Variables & $\operatorname{Prob}(\mathrm{Y}=0)$ & $\operatorname{Prob}(\mathrm{Y}=1)$ & $\operatorname{Prob}(\mathrm{Y}=2)$ \\
\hline Experience & $-0.012^{* *}$ & $0.009^{* *}$ & $0.002^{*}$ \\
\hline Education & $-0.044^{* *}$ & $0.036^{* *}$ & $0.008^{*}$ \\
\hline Milk Yield & $-0.027^{*}$ & $0.022^{*}$ & 0.005 \\
\hline Milking machine & $-0.287^{*}$ & $0.208^{*}$ & 0.078 \\
\hline Artificial insemination & $0.204^{* *}$ & $-0.169^{* *}$ & $-0.034^{*}$ \\
\hline Record keeping & $-0.337^{* *}$ & $0.249^{* * *}$ & 0.087 \\
\hline
\end{tabular}

*** $\mathrm{P}<0.01 ; * * \mathrm{P}<0.05 ;{ }^{*} \mathrm{P}<0.1$

Nearly half of producers $(46.76 \%)$ in Erzurum province, Turkey, had no memberships to any agricultural organizations while 32.38 and $20.86 \%$ were members to only one and two or more organizations, respectively (Sarı and Külekçi, 2017). Given the research findings in different regions of Turkey, it seems some significant differences in terms of percentages of producer's memberships to agricultural organizations.

The estimation results derived from ordered probit model is presented at Table 2. Since the model was found to be statistically significant at $0.01 \%$ level, the parameters could be interpreted. Experience, education level, milk yield per cow, ownerships of milking machine and keeping records on farms had positive; while artificial insemination had negative effects on farmers' memberships to agricultural organizations. The results are in accordance with economic theories and expectations.

The likelihood of being a members to more agricultural organizations increased in proportion to experience period in dairy cattle activities. One additional year in experience increased the likelihood of producers associated to any organization to being a member to one and two and more organization by 0.9 and $0.2 \%$, respectively while reduced the likelihood of not being a member by $1.2 \%$ for producers who had not memberships to any organizations (Table 3 ).

Memberships to more agricultural organization increased in line with education period of producers. One additional years of education period decreased the likelihood of not being a member to any organizations by $4.4 \%$ for those who had no memberships of organizations while increased the likelihood of producers associated with any organization to being a member to one and two or more organization by 3.6 and $0.8 \%$, respectively (Table 3). The research findings in South Eastern Anatolia Region (GAP) revealed that an additional year in education period of producers increased the likelihood of being a member to agricultural cooperatives by $16.5 \%$ (Karl1 et al., 2006). The likelihood of producers' being a member to one, and two or more agricultural organizations increased by 18.3 and $13.2 \%$, respectively, through one additional year to education period in Erzurum province, Turkey (Sarı and Külekçi, 2017). Similar findings were reported in researches conducted on producers in China (Zheng et al., 2012), Ethiopia (Nugusse et al., 2013; Chagwiza et al., 2016) and Nigeria (Ogunleye et al., 2015)

The likelihood of being a member to agricultural organizations increased in according to daily milk yield per cow, which comply with expectations. One $\mathrm{kg}$ increase in daily milk yield per cow reduced the likelihood not being a member by $2.7 \%$ for producers who had no memberships to any agricultural organizations, while increased the likelihood of being a member by $2.2 \%$ for those who had already a memberships. It was reported in the research conducted in Rwanda (Issa and Chryostome, 2015), Ethiopia (Chagwiza et al., 2016) and Nigeria (Odoemenem and Obinne, 2010) that producers who had a memberships to agricultural organizations were more productive and faster adapters to innovation.

The producers, who used milking machine were $28.7 \%$ less likely not being a member to any agricultural organization, while they were 20.8 and $7.8 \%$ more likely being a member of one or two and more agricultural organization, respectively. (Table 3).

The likelihood of being a member to agricultural organization were lower for producers who applied artificial insemination compared to those who didn't. This doesn't comply with expectations. The producers, who applied artificial insemination were $20.4 \%$ more likely not being a member to any agricultural organization, while they were 16.9 and $3.4 \%$ less likely being a member of one and two or more agricultural organizations, respectively. A great number of producers (68.2\%) didn't apply the artificial insemination. The reported rate of artificial insemination for dairy cattle farms in Gevaş district of Van province were reported as $43.2 \%$.

Artificial insemination is not common among the producers due to not fully developed artificial insemination services as in the western regions of Turkey (Thrace, Aegean and Eastern Marmara), low cow fertilization and relatively high charges of artificial insemination.

Record keeping play a great role in increasing the productivity and profitability rates for all sizes of livestock farms (Gökçen, 2014) .A farmer that kept records was more likely to use the records for monitoring, planning, selection decision and improving management efficiently than those who did not keep records (Issa and Chryostome, 2015).

The likelihood of being a member to any agricultural organization were higher for producers who kept records compared to ones who didn't. The producers, who kept records were $33.7 \%$ less likely not being a member to any agricultural organization, while they were 24.9 and $8.7 \%$ more likely being a member of one or two and more agricultural organization, respectively (Table 3). Gençdal et al. (2016), reported that the likelihood of keeping records of dairy cattle farms associated with İkizler Agricultural Development Cooperative in Gevaş district of Van Province were higher compared to those noneassociate with Cooperative. 


\section{Conclusion}

The research findings revealed that two third of the producers had no memberships to any agricultural organizations. It seems that the major factors effective on the memberships of agricultural organizations are education level and keeping records on the farms. Education regarding farm business and management and establishing efficient organizations will be helpful for profitability and sustainability of dairy cattle farms in the region. Government policies and supports could be designed in such a way that the producers would be encourage for memberships of agricultural organizations especially in terms of cooperation and confidence.

\section{References}

Abdel-Aty MA. 2001. Using ordered probit modeling to study the effect of ATIS on transit ridership. Transportation Research Part C: Emerging Technologies, 9(4): 265-277.

Akbay C, Tiryaki GY, Gül A. 2007. Consumer Characteristics Influencing Fast Food Consumption in Turkey. Food Control, 18: 904-913.

Akın F, Üçdoğruk Ş, Deveci I. 2000. Investigation of Households' Consumption Expenditures through Sequential Probit Probability Model, Turkish Statistics Institute, Research Symposium, 27-29 December, Ankara.

Bhuyan S. 2007. The People Factor in Cooperatives: An Analysis of Members' Attitudes and Behavior. Canadian Journal of Agricultural Economics, 55(3): 275-298.

Birchall S, Simmons R. 2004. What motivates members to participate in co-operative and mutual businesses? A theoretical model and some findings. Annals of Public and Cooperative Economics, 75(3): 465-495.

Chacko TI. 1985. Member participation in union activities: Perception of union priorities, performance and satisfaction. Journal of Labor Research, 6(4): 363-373.

Chagwiza C, Muradian R, Ruben R. 2016. Cooperative membership and dairy performance among smallholders in Ethiopia. Food Policy, 59: 165-173.

Daft RL. 2010. Organization Theory and Design. Tenth Edition. South-Western Cengage Learning USA.

Emeç H. 2002. Sequential Logit Estimates and Scenario Results for Aegean Region Consumption Expenditures. Journal of Social Sciences Institute of University of Dokuz Eylül, 4(2): 13-29.

Eraktan G. 2001. Basics of Agricultural Policy and Agricultural Support Policies in Turkey, Publication of Uzel Printing, ISBN 975-8437-01-1, İstanbul.

Everest B. 2015. A research on the perception of cooperative principles and analysis of factors affecting member participation in the cooperative management of Agricultural Credit Cooperatives: Case of Regional Union of Agricultural Credit Cooperative in Balıkesir. Ph.D. Thesis, Ege University, Graduate School of Natural and Applied Sciences, İzmir, Turkey.

Gençdal F, Terin M, Yıldırım I. 2016. A Comparative Study of Dairy Farms Associated and None-Associated with Agricultural Development Cooperatives Using Certain Criterias: A Case Study of Van Province of Gevaş District. Journal of Agricultural Faculty of Gaziosmanpasa University, 33(1): 1-8.

Gökçen H. 2014. The importance of keeping records in livestock http://www.hazimgokcen.net/hayvancilik/hayvanciliktakayit-tutmanin-onemi/ Accessed: 18.05.2018.

Greene WH. 2012. Econometric Analysis, Seventh Edition. Pearson Prentice-Hall, Upper Saddle River, New Jersey, 07458. ISBN 10:0-13-139538-6.
Inan IH, Kumkale I. Gaytancioğlu O. 1999. The Role of Agricultural Cooperatives, Producers' Unions and Peasant Serving Unions in Rural Organization in Thrace Region, Turkish Cooperative Institution Publications, No: 91 Ankara.

Inan IH, Direk M, Başaran B, Birinci S, Erkmen, E. 2005. Organization in Agriculture. $6^{\text {th }}$ Technical Congress of Agricultural Engineering 3-7 January 2005, p. 1133-1154 Ankara, Turkey.

Inan IH, Gülçubuk B, Ertuğrul C, Kantürer E, Baran EA. Dilmen, Ö. 2000. Rural Agriculture Organization in Turkey. 5th Technical Congress of Agricultural Engineering 17-21 January 2000, Vol.1: p.145-176, Ankara, Turkey.

Issa N, Chrysostome NJ. 2015. Determinants of farmer participation in the vertical integration of the Rwandan Coffee value chain: Results from Huye district. Journal of Agricultural Science, 7(9): 197-211.

Karlı B, Bilgiç A, Çelik Y. 2006. Factors Affecting Farmers' Decision to Enter Agricultural Cooperatives Using Random Utility Model in the South Eastern Anatolian Region of Turkey. Journal of Agriculture and Rural Development in the Tropics and Subtropics, 107(2): 115-127.

Karlı B, Çelik, Y. 2003. The Efficiency of Agriculture Cooperatives and Other Farmers' Organizations in Regional Development of South Eastern Anatolia Region (GAP), Agricultural Economics Research Institute No: 97, Ankara

Koçtürk OM, Özübilgin N. 2004. The position of professional farmer's organization of Turkey within the context of EU membership: The case of Union of Turkish Chambers of Agriculture. $6^{\text {th }}$. National Agricultural Economics Congress 16-18 September 2004, Tokat, Turkey

Mckelvey RD, Zavoina W. 1975. A Statistical Model for the Analysis of Ordinal Level Dependent Variables. Journal of Mathematical Sociology, 4: 103-120.

Nugusse WZ, Huylenbroeck GV, Buysse J. 2013. Determinants of rural people to join cooperatives in Northern Ethiopia. International Journal of Social Economics, 40(12):10941107.

Odoemenem IO, Obinne CPO. 2010. Assessing the factors influencing the utilization of improved cereal crop production technologies by small-scale farmers in Nigeria. Indian Journal of Science and Technology, 3(1): 180-183

Ogunleye AA, Oluwafemi Zacchaeus O, Arowolo KO, Odegbile OS. 2015. Analysis of Socio Economic Factors Affecting Farmers Participation in Cooperative Societies in Surulere Local Government Area of Oyo State. Journal of Agriculture and Veterinary Science, 8(5): 40-44.

Rehber E. 2009. Organization and Problems in Agriculture. http://www.erekonomi.com/orgut.pdf Accessed: 04.06.2009

RTMFAL. 2018a. Republic of Turkey Minister of Food, Agriculture and Livestock https://www.tarim.gov.tr/sgb/Belgeler/SagMenuVeriler/TR GM.pdf Accessed: 15.05.2018.

RTMFAL. 2018b. Republic of Turkey Minister of Food, Agriculture and Livestock https://www.tarim.gov.tr/sgb/ Belgeler/SagMenuVeriler/HAYGEM.pdf Accessed: 15.05.2018.

Sarı M, Külekçi M. 2017. Situation of farmers' cooperation and determination of factors affecting cooperation: Case study of Erzurum province. Iğdır Univ. J. Inst. Sci \& Tech. 7(1): 319-327.

Selznick P. 1948. Foundations of the Theory of Organization. American Sociological Review, 13 (1): 25-35.

Talim M, Güneş T, Çıkın A, Inan IH, Bektöre M. 1981. Organization in Agriculture. Second Turkish Agricultural Congress, Papers Books. Ministry of Agriculture and Forestry Publications, Ankara.

Terin M, Çelik Ateş H. 2016. A study on determining the factors affecting organization in Agriculture: A case in Van province. Turkish Journal of Agricultural and Natural Science, 3(1): 38-44. 
Yamane T. 1967. Elementary Sampling Theory, Printice-Hall Inc., Englewood Cliffs, N.T.

Yercan M. 2007. Cooperation pattern of Turkish and European Union agriculture and agricultural cooperatives. Turkish Journal of Agricultural Economics, 13(1): 19-29.

Yıldırım I, Sahin A. 2006. A Comparison of Profitability between Culture and Native-breed Dairy Farms (Case Study of Eastern Part of Turkey), International Journal of Dairy Sciences, 2(2): 136-145.
Yıldırım I, Terin M, Çiftçi K. 2008. The Influence of Scale on the Profitability of Culture-Cross Breed Dairy Cattle Farms in Western Part of Turkey, Journal of Animal and Veterinary Advances, 7(9): 1073-1077.

Zheng S, Wang Z, Awokuse TO. 2012. Determinants of producers' participation in Agricultural Cooperatives: Evidence from Northern China. Applied Economic Perspectives and Policy, 34(1): 167-186. 